\title{
In the margins of contamination: lead poisoning and the production of neoliberal nature in Uruguay
}

\author{
Daniel Renfrew ${ }^{1}$ \\ West Virginia University, USA
}

\section{Introduction}

In Uruguay in 2001, the mass media began reporting on a widespread epidemic of pediatric lead poisoning in the western Montevideo working class district of La Teja. Lead was discovered to be a multisource pollutant (from battery and metals factories, toxic landfills, automotive emissions, cottage industries, water pipes, and paints) of the air, water, and soil of Montevideo and several other cities, creating an unprecedented environmental health problem. Despite being the world's oldest environmental disease and a decades-long occupational and environmental hazard in Uruguay, lead poisoning was never before officially recognized as a problem. Lead contamination in Uruguay occurred in a context of widening social inequality and the dismantling of a welfare state once hailed as an "exceptional" model of development in Latin America. Amid processes of neoliberalism and regional integration through MERCOSUR, and despite a "Natural Uruguay" national marketing campaign that celebrates the country's environmental quality, lead became Uruguay's most extensive instance of environmental contamination and inspired the largest grassroots environmental movement in its history.

This article situates the discovery of lead poisoning within recent processes of neoliberal and environmental reform. It argues that industrial contamination and its socio-political responses have become prevalent and even predictable through neoliberal-inspired transformations in production and consumption, the dismantling of state services, and increased social vulnerability to affliction. Contrary to orthodox theories of neoliberal restructuring, however, environmental concerns have provoked state bureaucratic expansion, rather than contraction, bringing about new forms of environmental governance and enabling environmental politics across social scales. Neoliberal reforms in Uruguay have resulted in geographically uneven spatial arrangements, with ecology taking on central importance in both macro level development strategies as well as in grassroots responses to intensified or newly recognized socio-environmental hazards. This article analytically draws together neoliberalism and environmentalism, or the manifestations of "neoliberal nature" in Uruguay. It focuses on how the uneven character of neoliberalism structures risk and enhances vulnerability for masses of people while providing the political and bureaucratic tools for both the disciplining of human and biophysical nature, and the contestation of socially and environmentally destructive practices.

Lead contamination was intensified through a set of processes associated with neoliberal economic restructuring and the accumulated effects of de-industrial decline. I think of neoliberalism, following David Harvey (2005: 2), as a set of political economic theories and practices that proposes that "human well-being can best be advanced by liberating individual entrepreneurial freedoms and skills within an institutional framework characterized by strong private property rights, free markets, and free trade." The state serves as guarantor of the conditions making market freedoms possible, most often through deregulation and the privatization of former state-run enterprises or services. Market competition is envisioned, in theory, on a global rather than nation-state plane. At the same time, the state cuts costs by withdrawing various social democratic-style welfare provisioning services. Neoliberal reforms in Uruguay, a country long celebrated as Latin America's "exception" and a model for social democratic development and governance in the region, are fiercely contested and draw strong symbolic and ideological responses. Uruguayan nature, under a neoliberal regime, is conceptualized and acted upon through discourses of "sustainability," which I argue play a fundamental role in setting the stage for large-scale and potentially environmentally destructive multinational investments. Discourses of sustainability, furthermore, serve to obscure recognition of and

\footnotetext{
${ }^{1}$ Assistant Professor of Anthropology, Division of Sociology and Anthropology, West Virginia University, PO Box 6326, Morgantown, WV 26506-6326, USA. Email: Daniel.Renfrew "at" mail.wvu.edu. The paper is based on eighteen months of dissertation research conducted in Uruguay from January 2004-June 2005, and a follow up trip in November 2005. Research was generously funded by grants from the Wenner Gren Foundation for Anthropological Research and the International Institute for Education's Fulbright program, as well as a Rosa Colecchio travel award for dissertation research enhancement from Binghamton University-SUNY, USA. I am grateful for the critical and informative commentary of my dissertation committee members, Carmen Ferradás, Thomas Wilson, Douglas Holmes and Nancy Appelbaum. A previous and shortened version of this paper was presented at the XXVII International Latin American Studies Association Congress in Montreal, Canada, September 2007, and benefited from the comments of discussants Carmen Ferradás and Gastón Gordillo. Many thanks to Josiah Heyman for his astute and critical suggestions on a previous draft. Any remaining errors or shortcomings in this paper are of my sole responsibility. This paper is part of the 2008 Eric Wolf Prize special feature, edited by Timothy Collins and Josiah Heyman.
} 
interventions into the lead contamination problem and other socio-environmental hazards, raising broader questions about the political uses of nature and their effects on environmental degradation, governance, and politics.

\section{The production of nature in Uruguay}

Traveling through Uruguay's countryside, one discovers a bucolic landscape of rolling green hills dotted with clumps of trees, intermittent streams and ever-present cattle, sheep and birds. The nature of Uruguay, the Guaraní name meaning "river of the country of birds" (A. Trigo 1990: 9) does not conform to the dominant western romantic tropes of "third world" nature. There are few forests and vegetation is thin, there are no "forest peoples" or indigenous populations, and there is a general absence of large wild animals, the "charismatic megafauna" (N. Smith 1996) that have become some of the developing world's most iconic symbols. Uruguay's 3.2 million people are over $90 \%$ urban based, with well over half of the country's population settled in the Montevideo metropolitan area (Figure 1). The rest are mostly concentrated in cities and villages of the interior, leaving vast expanses of pasturelands throughout most of the territory's 176,215 $\mathrm{km}^{2}$ (68,000 miles²), in which the occasional modern day gaucho on horseback often symbolizes the lone human presence.

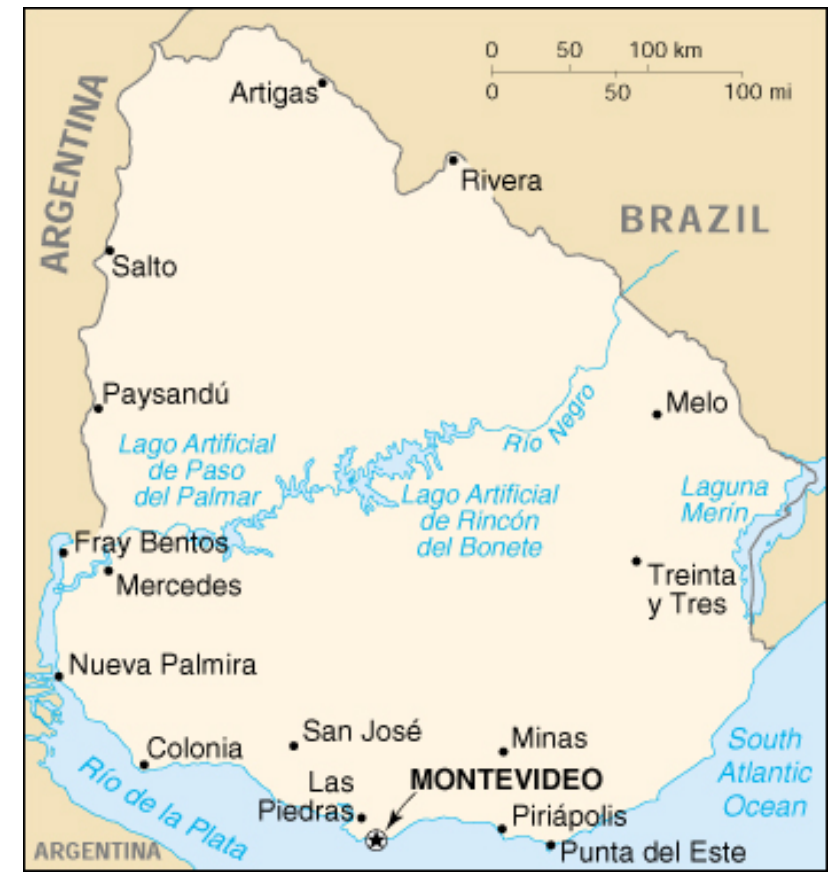

Fig. 1:. Uruguay map (Source: http://www.rau.edu.uy)

Uruguay's landscape is socially mediated and has been produced historically (N. Smith 1996) and in relation to the international capitalist division of production (F. Coronil 1997). Prior to colonization, Uruguay was sparsely populated by Charrúa Indians and other semi-nomadic indigenous peoples. In the seventeenth century, European colonists introduced cattle grazing (M. Achkar et. al. 1999: 22). By 1780 the meat salting industry replaced leather as the principal commercialized product, with incipient forms of agriculture directed towards the internal market. Cattle grazing expanded after 1860 as once-endemic civil wars diminished, bringing about relative political stability in the countryside. By the end of that decade the introduction of sheep modernized and capitalized Uruguay's livestock farming (agropecuario) system, with wool overtaking leather and beef as the primary export commodity by the 1880s (M. Achkar et. al. 1999).

Agriculture in Uruguay has always played a secondary role, with a few crops oriented to the internal market until the late twentieth century when commercialized crops were subjected to green revolution technologies. This technological change facilitated the concentration of farms, increased yields and supported a burgeoning export industry, particularly of rice and soy, and more recently, commercial tree plantations for the international pulp and paper industry. Uruguay's basic productive orientation has remained more or less intact, however, established nearly 400 years ago as a "giant ranch looking out to the sea" (M. Achkar et. al. 1999: 34). The relative wealth generated from this productive base shaped the conditions for the 
redistribution of wealth and implementation of advanced social welfare reforms in the early twentieth century. Under the great modernizer José Luis Batlle, the batllista system of state-led development, progressive legislation, and a democratic political system and institutional culture, served as a model in the region and laid the foundation for Uruguay's quasi-mythical status as the "Switzerland of South America."

The batllista system began stagnating by the mid-twentieth century, however, coinciding with the eclipse of the import-substitution industrialization (ISI) model, as was the case throughout most of Latin America. Latin America's debt crisis and its dependence on newly restricted private bank credits led the economies of the region to turn to the IMF and the World Bank for desperately needed loans. Structural adjustment programs were imposed as loan conditions, introducing an era of neocolonial and neoliberal economic policies. The subsequent economic and state "adjustment" or restructuring mandated the radical reduction of the state's role in welfare provisioning, social spending, public sector employment and public subsidies; currency devaluations and fixed exchange rates, interest rate liberalization and fiscal discipline; wage restrictions and labor "flexibility"; greater foreign investment and imports access through reduced tariffs, privatization and open markets; and the export of mono-cultivated agriculture, raw materials and primary manufacturing goods (W. Canak 1989; M. Edelman 1999: 83-84; S. Radcliffe 2005).

The basis of the Uruguayan agro-productive system remains livestock, but the past four decades in Uruguay have witnessed the internationalization of the agro-export economy, more dependant than ever on fluctuating world markets. The "finance bourgeoisie" eventually gained hegemony over the large landowners that previously dominated Uruguayan political economy (M. Achkar et. al. 1999: 38). Landholdings became concentrated and soils were increasingly degraded through the application and abuse of green revolution technologies and chemical inputs. Consequently, 41\% of rural producers disappeared from 1961 to 1995 and the rural population was reduced from 19\% in 1963 to 9.2\% in 1996 (M. Achkar et. al. 1999: 47-54). Uruguay's deepening poverty and "rural exodus," similar to the effects of the free market onslaught on other Latin American countries (cf. M. Edelman 1999; J. Gledhill 1995), is largely responsible for the presently depopulated countryside. Rural poverty reached critical levels in recent years, provoking migration to cities and the explosive growth of squatter settlements, or "asentamientos" as they are known in Uruguay (J. Corboz 2005).

With the economic, social and political crisis beginning in the late 1950s and 1960s, Uruguay gradually lost its status as South America's model Republic, the "mirror of Europeans and envy of Americans" (A. Trigo 1990: 159). While maintaining a productive base in the livestock industry, finance and services partially eclipsed livestock and manufacturing in their contributions to the gross national product. As tourism gained central importance for the economy, becoming the largest foreign currency earner in the 1990s, the Uruguayan business and political elite initiated a project of place promotion centered on the marketing of the country's beaches and countryside under the product slogan "Uruguay Natural." Uruguay, according to this project, would become a service center of regional and global finance, conferences, tourism, and a general "gateway to Mercosur" (A. Campomar and B. Andersen 1999; D. Renfrew 2004a).

Ecology is of central importance in the Uruguay Natural campaign for attracting foreign investors and tourist dollars. The Uruguayan countryside, once considered hostile and threatening or culturally backward and primitive, has been re-presented as an arcadia of beautiful landscapes and quaint traditions, a natural Eden for the ecologically sensible. The revalorization of the natural has coincided with rising forms of "green" consciousness, reflecting broader socio-political processes. From pervasive negative or distanced images of the past century and a half, the natural has awakened a renewed importance in present day Uruguay. Romantic portrayals of rural nature have resurfaced, but are emptied of the wild, anarchic or "barbarous" elements that characterized nineteenth century imagery. In the twenty-first century, nature is presented in terms of human intervention and management (S. Franklin et. al. 2000), or as a packaged commodity for "consumption" (A. Escobar 1999).

Uruguay Natural brochures promoting foreign tourism in Uruguay in 2002 referred to the country alternately as a "green retreat," a "freshwater paradise," and a "natural miracle." Boasting of Uruguay’s sixth-place ranking in the 2002 World Sustainability Index, one English-language brochure characterized Uruguay as: "A country with a great diversity of sceneries, combining in perfect equilibrium the protection of the environment with the social needs for development of its inhabitants, a place where peace and tranquility reign supreme."

As the "natural country" slogan developed into an "export line" (MVOTMA 2002), various forms of eco-tourism were promoted through the green marketing of Uruguay's beaches and coastline; seal, whale, and bird watching; rural estancias; thermal bath resorts along the western Uruguay River watershed; and fishing or tours of interior rivers, streams, and marshes (Figure 2).

The redefinition of Uruguayan nationhood is largely a political response to regional and global conditions. Economic restructuring steered the economy away from industrial production and towards a regional repositioning that included a campaign of place promotion to distinguish Uruguay as the administrative capital of Mercosur, and a regional center of banking, conferences, tourism, and other services (D. Renfrew 2004a). The 2001 Argentine economic collapse and the regional and national recessions have undermined the "new Uruguay" political project, however, and with it the conservative and free market 
oriented Colorado Party administration of Jorge Batlle (1999-2004). The coming to power of President Tabaré Vázquez and the center-left Frente Amplio coalition in 2005, part of a broader left and center-left shift in the region, was largely based on an anti-neoliberal platform of renewed classic state-led production, reflecting a resurgence of a modernist-era national identity and a quest for sovereignty through left nationalism (D. Renfrew 2004b).

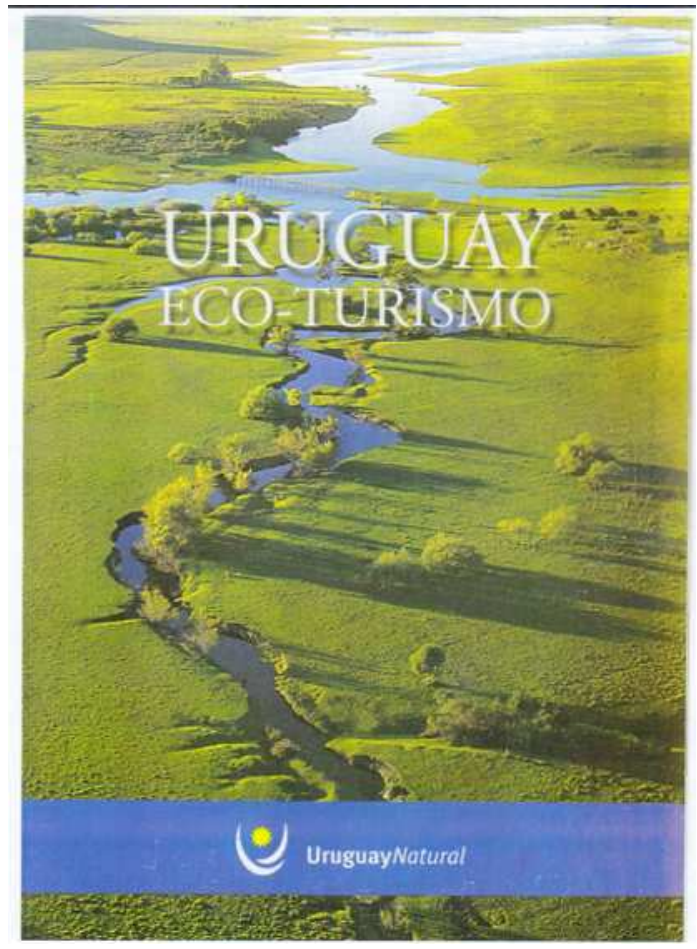

Fig. 2: Eco-tourism brochure (Ministerio de Vivienda, Ordenamiento Territorial, y Medio Ambiente)

\section{Sustaining development}

The Uruguay Natural campaign responds to a United Nations-inspired form of sustainable development. This is the broad discourse that has its origins in the perceived crisis of nature and development as recognized at the 1972 Stockholm UN Conference on the Environment, followed by the Club of Rome's Limits to Growth publication, the 1986 Our Common Future publication, and finally the 1987 Brundtland Commission Report (of the World Commission for Environment and Development). The Brundtland Report coined and defined "sustainable development" as development "that meets the needs of the present without compromising the ability of future generations to meet their own needs" (cf. W. Sachs 1999).

The series of UN Conventions, reports, and documents that followed set out a blueprint and system of international regulation of environmental problems, controlling the production and distribution of chemicals, waste, toxins, and emissions, and promoting the protection of ecosystems, biodiversity, and the ecological commons through conservation programs. An international model of sustainability and environmental protection, informed by the expert knowledge of Northern-based scientists and technocrats, became the de-facto model for the governance of peoples and resources around the world (A. Escobar 1996). With the mandated reduction of state powers, NGOs were positioned as the primary vehicles of environmental governance. In South America, environmental, development, and other NGOs, often directly linked to multilateral institutions and Northern funding agencies, experienced an explosive growth during the post-dictatorship period of the mid-1980s, filling the void of the retreating welfare state (F. Babb 2001; C. Ferradás 1996: 87). By the 1990s, many NGOs directly incorporated the goals of sustainable development.

Critics have linked the discourse and ideology of sustainable development to a project of continued economic growth serving as damage control for the concerns of environmental groups and citizens over environmental degradation (A. Escobar 1996; E. Hartwick and R. Peet 2003). As Timothy Luke argues (2006), the system could be better defined as one of "sustainable degradation." Ecological degradation is "lessened but never stopped": "[I]t is instead measured, monitored, and manipulated within certain tolerances" through strategies and systems of environmental governance (T. Luke 2006: 100). 
As sustainability becomes "mainstreamed," incorporated into the agendas of global multilateral institutions such as the World Bank, International Monetary Fund (IMF) and World Trade Organization (WTO), it turns into "the effects that the majority of people can be persuaded to find tolerable, as the necessary environmental consequences of an even more necessary growth process" (E. Hartwick and R. Peet 2003: 209). Problems of development in the South are now largely recast as ecological, managed through new environment ministries and expert regimes (C. Ferradás 1998: 11).

While environmental NGO's became more sophisticated and increased their ties to the global funding circuit, a series of loosely organized grassroots initiatives were taking shape in Uruguay, forming a burgeoning popular environmentalism that largely grew in parallel to and sidestepped the longer established but largely bureaucratized and increasingly elitist NGO community. Environmental issues in Uruguay were being addressed during the 1990s, and in the new Millennium, like never before. The organizations and groups involved had increasingly divergent class characters, however, with the larger, well funded organizations employing methods and serving agendas and issues largely divorced from the lived realities of ordinary citizens.

Activists have complained in reference to the lead issue, for instance, that for Uruguayan NGOs, "saving a whale is more important than saving a child." While somewhat unfair as a blanket assessment, this charge reveals contested versions of environmental perception and politics in Uruguay. Nature, in Uruguay as elsewhere, functions as a means of political action, a prism through which to understand broader social processes, and a vehicle for new forms of social control, disciplining, and government. The lead issue and the rise of the anti-lead movement cannot be adequately analyzed without an understanding of the multifaceted, contested, and sometimes contradictory or paradoxical forces at work in the production of nature.

\section{Showcasing ecology}

Neoliberal development strategies in Uruguay produce an uneven spatial arrangement characterized by what could be termed a "showcase ecology" in select regions coupled with socio-environmental neglect and degradation in others. I argue the overarching purpose of creating a showcase ecology governed by principles of sustainable development is to highlight a stable and orderly business climate for foreign investment that draws the country in line with global corporate mandates. The realities of uneven capitalist development in a peripheral nation such as Uruguay necessitate parallel economic practices that draw from informal, unstable, and disorderly forms of economic development. Government and business leaders use sustainability as an ideological and political tool in this tiered system of ordered and disorderly capitalism, drawing attention to the former while disassociating with, veiling, or dismissing the socio-environmental consequences of the latter. As Harvey notes (2006: 42), and as evidenced in Uruguay, uneven development deems certain territories will "advance spectacularly" at the expense of others.

The Uruguayan government's report to the Johannesburg 2002 World Summit on Sustainable Development reveals the strategic uses of sustainability as an investment strategy. The report details the state of the environment, the country's compliance with international treaties and protocols and its general progress in the decade following the 1992 Rio Earth Summit (MVOTMA 2002). The colorful document is full of beautiful pictures of natural areas in Uruguay, its flora and fauna, rolling hills and valleys, and remote ocean beaches. Absent are pictures of urban industrial pollution, littered city streets and lots, clandestine toxic dumps, garbage-strewn rivers or the poverty and social suffering found in Uruguay's asentamientos.

Parts of the Johannesburg environmental report are borrowed directly from Uruguay. Open for Growth, a book issued by the Uruguay XXI Investment and Export Promotion Agency (A. Campomar and B. Andersen 1999). Uruguay XXI is a government-funded agency that works with private banks and interests in promoting the "Uruguay Image" abroad in order to "facilitate the internationalization of the economy" and to set up the country as a "gateway to Mercosur." The book’s opening lines read: "Uruguay is a phenomenon among emerging markets in Latin America. In the last two decades, this small, export-driven economy has come back from economic stagnation to become one of the most politically, economically, socially and legally stable countries in Latin America with one of the most open investment environments" (A. Campomar and B. Andersen 1999: 1).

As suggested by the Uruguay XXI marketing book, the relationship between the government and business elites rests on maintaining stability as a precondition for foreign investment in order to secure the "good business climate" necessary for the country’s "internationalization" and modernization. According to Harvey (2006: 25), "The fundamental mission of the neo-liberal state is to create a 'good business climate' and therefore to optimize conditions for capital accumulation no matter what the consequences for employment or social well-being." Ecological stability, in a post-Rio 1992 world where the environment has become a key site and strategy of development, joins and intersects with the economic, political, social, and legal forms of stability lauded by the theoreticians of a neoliberal order. As "primitive" forms of capitalist exploitation of nature and resources become a primary vehicle of profit making, the strategy of "accumulation by dispossession" requires a functional and efficient legal and political infrastructure to make 
it possible, in addition to a suitably disciplined labor force and citizenry. While the general thrust of neoliberal economic theory and practice is towards de-regulation and the scaling back of state functions, this "does not mean that all regulatory activity desists," as Harvey points out (see also G. Bridge and A. Jonas 2002; N. Castree 2008). The state must ensure "accountability" and "cost effectiveness" for capital accumulation, even if that means expanding in key areas of infrastructure and the public sector (D. Harvey 2006: 25). Holding up to the world a showcase ecology, therefore, can act as a powerful signal that Uruguay is "ready for business."

The Uruguayan Johannesburg environmental report discusses the institutional infrastructure and legal frameworks devised to protect the environment, most of which were created around the time of the Rio Earth Summit. The environmental report focuses on the state's institutional regulatory capacity and functions, however, without providing information on existing levels of industrial or agricultural pollution or an evaluation of the actual controls of emitted waste. In contrast to a brief mention in the marketing book, the Johannesburg report does not acknowledge industrial pollution as a serious environmental issue in Uruguay, and it makes no mention of heavy metals contamination even though the report was issued a year after the lead contamination discoveries blanketed the media and forced the state to mobilize some of these same institutional frameworks.

Uruguay's international image becomes sheltered from scrutiny as the environmental indicators it provides to the international community affect international ratings and ranking systems such as the World Sustainability Index. ${ }^{2}$ The government hides behind the glossy pictures and greened images of a bucolic landscape and enviable sceneries, veiling and ignoring other realities.

Environmentalists have pointed out the paradoxical contrasts between the apparently pristine ecological conditions of Uruguay and its serious but often invisible environmental hazards. Despite the ubiquitous chemical contamination of the country's lands, water and air; the production, according to Environment Ministry figures, of over two million tons of industrial waste per year with no facility yet set up to manage it; and the various environmental conflicts and disasters that have afflicted the country in recent years, Uruguay improved on its 2002 position of sixth place to become number three in the world sustainability ranking of 2004, behind only Finland and Norway (La República, January 25, 2005).

The paradox of coexisting urban environmental degradation with internationally lauded environmental indicators underscores the uneven nature of development and profound differences in ways of perceiving, measuring, and experiencing the environment. The Sustainability Index takes into account a broad-based, macro view of environmental indicators, rather than accounting for the uneven distribution of environmental hazards and risks within cities and regions. It also projects site-specific environmental conditions based on a western-centered model of environmental desirability to the rest of the world and across heterogeneous ecological conditions.

The Sustainability Index methodology fails to take into consideration environmental problems that are relevant to the Uruguayan context, including the progressive loss of wetlands, the fragmentation of ecosystems, the distribution of heavy metals and lead contamination, soil erosion, low levels of recycling, and the ineffectiveness of environmental regulations (Caffera 2004; Evia 2002). Furthermore, annual forestation rates of $0.25 \%$ helped Uruguay boost its position in the ranking even though it was through the commercial planting of exotic species (Evia 2002). According to a broad-based eco-systemic view, or one that takes as a starting point what Wolfgang Sachs (1999) refers to as the "astronaut's perspective" on global environmentalism, higher rates of forestation in Uruguay may translate into more "breathing lungs" for the globe, supposedly reducing global carbon emissions and fulfilling the goals of the Kyoto Treaty.

Showcasing the new forest ecology, however, also reveals the economic interests at stake that go beyond mere differences in environmental perspective. The Uruguayan government used the Johannesburg report to market its "innumerable natural advantages for forest development" and its "modernized [forestry] legislation" (MVOTMA 2001: 33). While acknowledging (without naming) the potentially negative environmental impacts of forest development, the Johannesburg report assures these can be "adequately mitigated" through an ambiguously defined "sustainable forestry" (MVOTMA 2001: 34). Showcase ecology, again, becomes a means to promote capital accumulation in certain regions, in conjunction with and at the expense of the growing and dire environmental problems facing others.

\footnotetext{
${ }^{2}$ The World Sustainability Index ranking is presented yearly at the World Economic Forum in Davos, Switzerland. It is based on a quantitative system developed by Yale and Columbia University researchers that ranks 146 countries on their "sustainability" according to water and air quality and a list of 75 environmental and health indicators (cf. Barringer 2005).
} 


\section{Uruguay's "Pandora's box" of environmental conflicts}

Montevideo's environmental problems are evident to anyone who lives or ventures beyond the central and eastern sections of the city. The Pantanoso River borders the northwestern edge of La Teja and together with the Miguelete River to the east, provides La Teja with a spatial embrace of industrial and domestic waste and water-borne illnesses. A human geography of squatter settlements follows the bands of these rivers, susceptible to flooding and the multiple poisons carried by the rivers (Figure 3). Leather tanneries along the Pantanoso shores dump untreated wastewater into the river accumulating 160 metric tonnes (176 US tons) of Chromium per year (P. Muniz et. al. 2004: 1022). Both the Pantanoso and the Miguelete flow into Montevideo Bay, leading to waters highly polluted with lead, chromium, mercury, copper and other heavy metals (P. Muniz et. al. 2004: 1023).

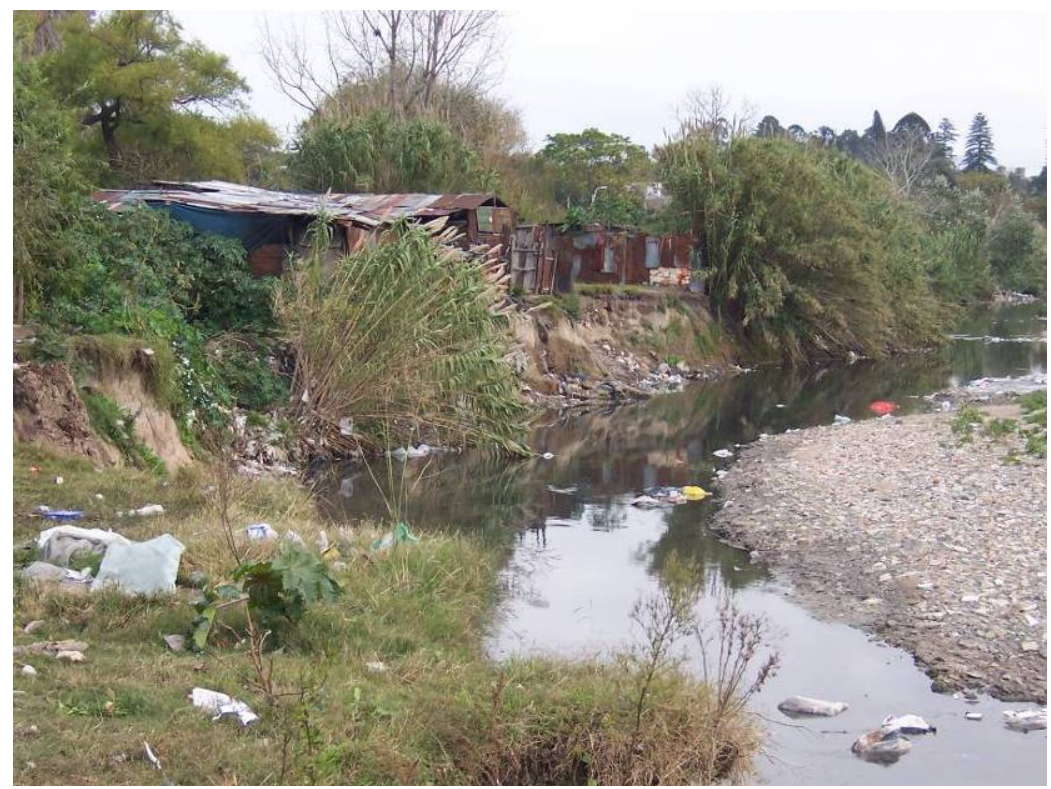

Fig. 3: Squatter settlement along Miguelete River, Montevideo (photo by author)

All of the urban waterways of Montevideo face varying degrees of contamination. Few national norms exist for solid and industrial waste disposal, there are no hazardous waste or incinerator facilities in the country, and monitoring and enforcement of existing laws are inadequate (M. Caffera 2004). Illegal garbage dumps are spread throughout Montevideo and there are inadequate recycling facilities or programs for solid waste (IMM 2005).

The green revolution dovetailed with neoliberal reforms favoring large landholdings and production consisting of heavy technological inputs, genetic seed imports, and agrotoxic chemical use. Since bigger companies and landholders could afford these changes, in addition to qualifying for international credits and loans, the effects were to squeeze out small and medium enterprises (see also G. Collier 1999; A. Goodman and M. Watts 1997). A dramatic fall in the price of agricultural goods during the 1990s, coupled with the introduction of canned, processed and imported foods, led to a loss of production among small enterprises and the rural exodus to the cities described above (D. Panario et. al. 2000). A spike in foreign acquisitions of landholdings in Uruguay has accompanied these policies, tied in particular to commercial crops and forestry. Critics charge this incremental "foreignization" (extranjerización) of land through rampant speculation threatens national sovereignty through possible job loss and growing food insecurity.

While the recent economic crisis temporarily diminished industrial emissions, it also served to weaken regulatory controls and foment a desire for production at any cost. Scientists and regulators in Uruguay have scrambled to react to environmental problems rather than fomenting research and a thorough evaluation of environmental risks. As geologist and environmentalist Daniel Panario stated in a media interview, the environment is a "Pandora's box" where "the gravest problem is the last one we've studied" (C. Amorín 2003).

\section{Lead poisoning and neoliberalism}

Mid twentieth-century ISI policies introduced heavily contaminating domestic industries, particularly in the battery, metals, and tannery sectors. As high tariffs limited imports and sparked a relative 
industrial boom, domestic industries turned to often innovative but highly contaminating practices. The ISI period storage battery industry, for example, consisted of collecting old batteries, smelting and refining their lead, and then re-assembling the batteries. In this way national industrialists could cover all phases of the production cycle and limit dependence on imports. The lead smelting chimneys contaminated the grounds, air, and surroundings of the factories, however, and the highly toxic lead oxide waste was dumped at various sites around Montevideo and its outer edges (D. Renfrew n.d.). For much of the twentieth century, industries dumped waste and emissions directly into streams and empty municipal and peripheral lots. The environmental and health consequences of indiscriminate polluting remained largely unrecognized, however, due to a paucity of institutional and academic resources directed toward addressing urban pollution, as well as a general popular acceptance of the perceived costs of modernization.

Occupational lead exposure, on the other hand, has long been a serious concern for workers and provided until recently the only known medical studies on lead poisoning in Uruguay. Workers were often denied access to their medical records, though, limiting popular understanding of the disease known as "saturnism," or of its potential hazards beyond the workplace. The use of lead paints, water pipes, and other sources of environmental exposure also contributed an unknown lead burden to the population at large. While lead contamination in Uruguay has existed for decades, much of it introduced or heightened through ISI policies, neoliberalism brought forth important changes in the sources and pathways of, and vulnerability to, environmental lead exposure. New productive and consumption practices, the dismantling of welfare services, and the crises in the economic, housing, and public health spheres, arguably linked to neoliberal reforms, directly increased the urban population's exposure to lead, as well as heightening vulnerability to environmental toxins.

Neoliberal market logic promoted the development of new export industries and manufacturing technologies, some of which intensified lead exposure. The industrial use of lead in Uruguay increased during the 1990s, according to the Occupational Health Commission of the Uruguayan Medical Syndicate, with new industries such as plastics and electronics increasingly replacing more traditional uses of the metal (SMU 2001: 2). The tannery industrial sector introduced in the late 1980s a lead-based wool "whitening" (nevado) dyeing process. With wool and leather tanneries concentrated along the Miguelete and Pantanoso River basins of western Montevideo, industrial contamination exposed the neighboring populations of Nuevo París and La Teja to concentrated levels of lead and other heavy metals and toxins (R. Bernardi and T. Paez 1999; Figure 4).

The government, following regional trends, introduced a floating currency and reduced tariff regime in the late 1980s, opening the economy to an influx of imported consumer goods and ushering in previously limited forms of consumer capitalism. It is not clear how many imported or nationally fabricated consumer products contained lead, but the use of lead in toys, paints, food products and other consumer items was not regulated until 2001. Of the few data available, studies in the 1990s indicated a prevalence of lead tainted alcohol and soda beverages (A. Schutz et. al. 1997). With a boom in new automobile sales in the 1990s, the associated sharp increase in urban vehicular traffic intensified exposure risk through leaded gasoline. Uruguay employed among the world's highest levels until 2000 of the tetraethyl lead (TEL) gasoline additive (S. Tong et. al. 2000: 1073). ${ }^{3}$ Decades of leaded gasoline use have significantly contributed to the urban population's long-term lead exposure, providing a "baseline" blood lead level in the 1990s and early 2000s that was more or less equal to the WHO and CDC's threshold for lead poisoning (10 $\mu \mathrm{g} / \mathrm{dl}$, or 10 micrograms of lead per deciliter blood).

Following the Uruguayan economic downturn of the late 1990s, political pressures for a less rigid regulation of industrial activity resulted in the loosening of municipal and federal oversight of industrial emissions, increasing direct pollution in urban centers (M. Caffera 2004). Urban infrastructure suffered from federal economic constraints, and combined with charges of widespread corruption, the coffers of state enterprises such as water (OSE) were gutted. OSE prioritized the extension of potable water services rather than replacing old pipe connections in already-serviced areas, thereby neglecting a decaying system of 300,000-600,000 pre-1982 lead water pipe connections in the country. Along with the continuing existence

\footnotetext{
${ }^{3}$ C. Anido et. al. (2000: 188) signal the economic opening of 1985 following the dictatorship as sparking the first wave of automobile imports, with a sharp rise in private automotive sales since 1995. The Montevideo Municipality (IMM 2005) identifies 1990-1997 as the period with the largest increase in vehicular circulation in the city. I compared TEL levels in Uruguayan gasoline during the 1990s, based on ANCAP figures, to the S. Tong et. al. (2000) report on world TEL levels. ANCAP used over $1.0 \mathrm{~g} / \mathrm{L}$ of TEL in 1991 in one gasoline product, and a maximum of $0.8 \mathrm{~g} / \mathrm{L}$ of TEL until 2000, when levels were lowered to $0.22 \mathrm{~g} / \mathrm{L}$. Tong et. al. (2000) cite some African countries' use of $0.8 \mathrm{~g} / \mathrm{L}$ as among the world's highest TEL levels. ANCAP emphasized (in media statements) that the TEL limit of 0.4g/L recommended by the United Nations and the World Bank since 2001 "doubles" ANCAP's usage, but they neglect to draw attention to the 1990s figures. Leaded gasoline in Uruguay was finally phased out in June 2004.
} 
of widespread lead pipe connections, OSE maintained from 1982-2007 a water quality standard permitting $50 \mu \mathrm{g} / \mathrm{L}$ of lead, or five times the World Health Organization's recommended limit. ${ }^{4}$

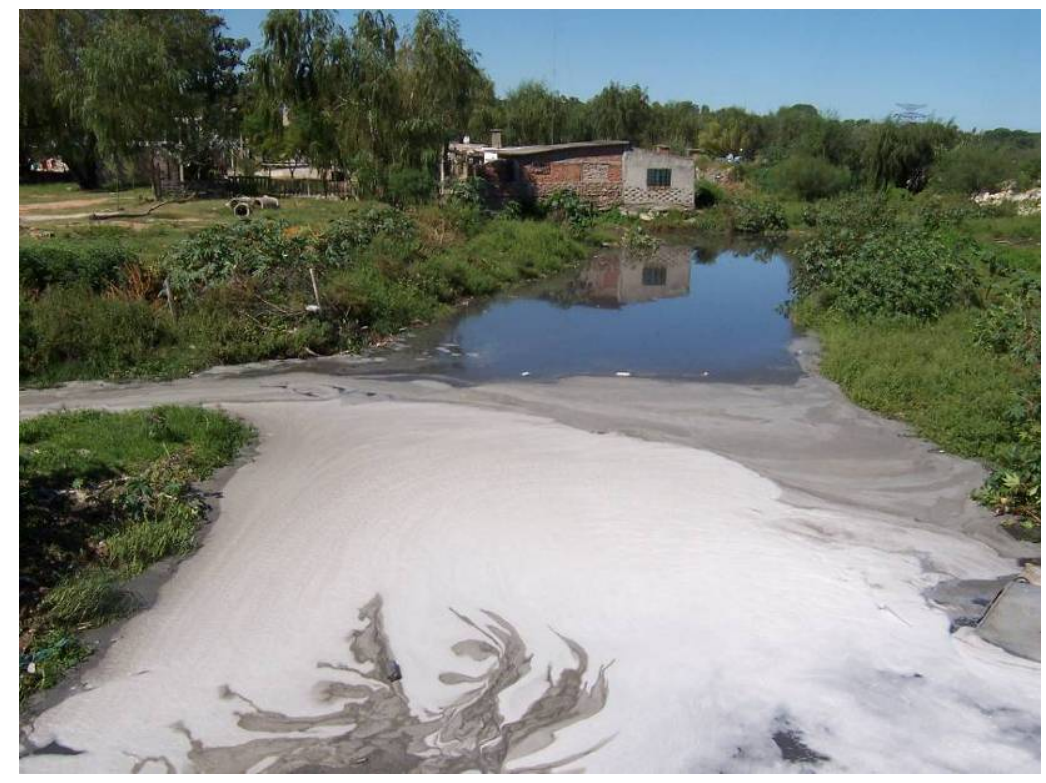

Fig. 4: Industrial waste flows into La Teja waterway (photo by author)

Growing impoverishment and unemployment fueled a housing crisis compounded by IMFmandated reforms of the heavily indebted Uruguayan Mortgage Bank (BHU). The reforms drastically reduced housing credits and helped push unprecedented numbers of people from formal housing into makeshift squatter settlements (P. Apezteguía 2007). Many of these settlements were built on marginal lands long contaminated by industrial waste, particularly from the battery and metallurgic industries. In La Teja, industrial waste was used as landfill primarily from 1969-1980, when the area's population expanded and workers settled near industrial employers (Figure 5). The housing from this period was generally made of solid material and integrated into the urban infrastructure, and the landfill was necessary due to the gaping holes left from an earlier period (late $19^{\text {th }}$ and early $20^{\text {th }}$ centuries) in which local quarries provided the raw material for the geographic expansion of Montevideo. The squatter settlements, on the other hand, were built since the 1980s on remaining empty lots of landfill, along flood-prone riverbanks, or in the case of one La Teja settlement, on the grounds of an abandoned scrap metals smelter.

The growing informal economy of the 1990s and 2000s, stimulated by unemployment and economic recession, included concentrated and highly polluting battery, metals and waste recycling, often conducted in close proximity to residential spaces. Some cottage industries such as the making of lead fishing weights have a longer history in Uruguay but were only identified recently as a hazardous activity. Others like "cable burning," or the melting down of stolen cables for heavy metals resale, proliferated since the 1990s. Cable burning, normally a clandestine activity conducted close to homes or residential areas, releases highly toxic lead vapors in the immediate vicinity of the activity, and deposits high concentrations of lead in soils where the smelting is conducted. Finally, an international trade in battery contraband with Brazil is an open secret that results in the dumping of much of the up to 1,000,000 kilos handled in the illegal recycling industry (R. Legnani 2002: 14; D. Renfrew n.d.).

\footnotetext{
${ }^{4}$ In 2007, OSE reduced its lead water quality standard to $30 \mu \mathrm{g} / \mathrm{L}$, still tripling the WHO's recommended limit. The state utility company continues to claim no responsibility in the country's lead contamination problem and only admits some elevated lead readings "in the past." Paradoxically, OSE nevertheless suggests letting first use faucet water run for "a few brief minutes," though it has never mounted any systematic public information campaign to raise awareness of the risks of lead in drinking water (OSE 2007).
} 


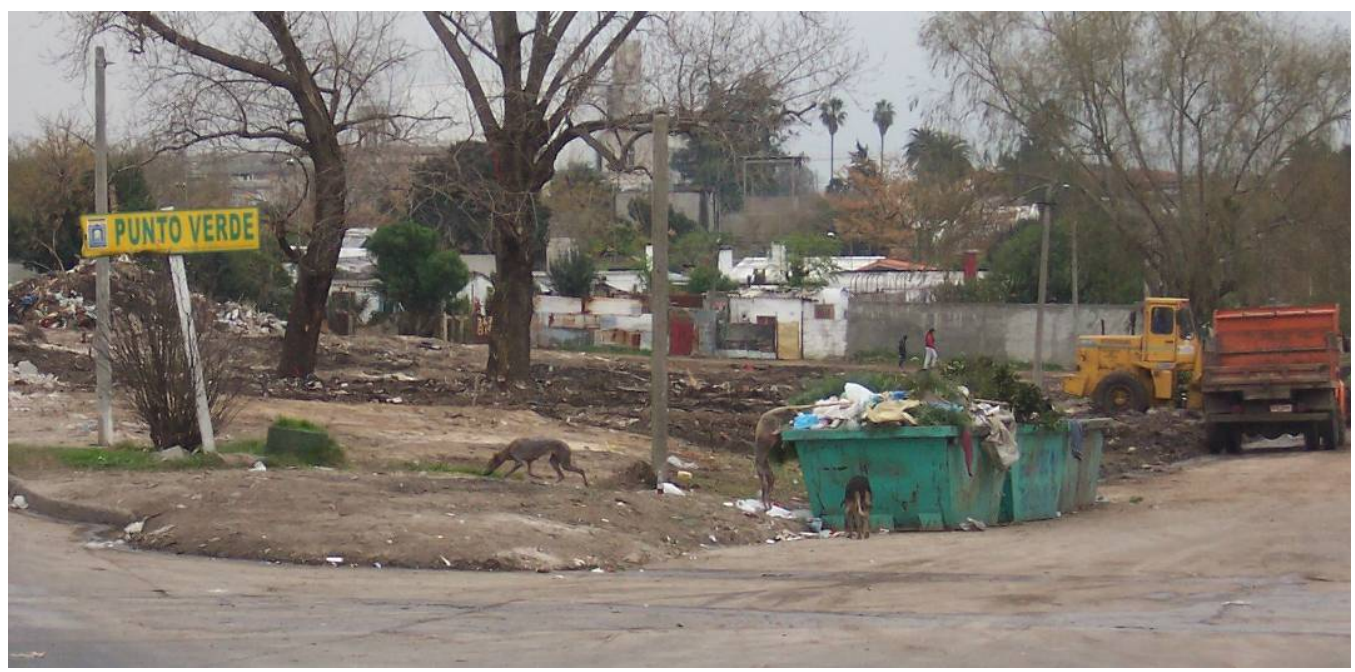

Fig. 5. Area of high lead contamination, former squatter settlement site, La Teja (photo by author)

Neoliberal restructuring and socio-economic decline in Uruguay, then, resulted in both new and intensified exposure rates of lead for the general population, with children, pregnant women and the "new poor" facing differential levels of risk and vulnerability. The decline in quality of health care and services to low-income families increased risk for vulnerable subpopulations for which poverty and malnutrition conditioned and limited their ability to mitigate the impacts of toxic exposure. ${ }^{5}$

The dynamics of the lead poisoning discoveries are better understood if placed within the general context of social exclusion and dissolution of the free market city. Environmental conditions largely coincide with socio-economic ones and are subjected to the same general forces of fragmentation and homogenization. Contaminated communities are superimposed upon polluted landscapes in poor sections of the city, inversely mirroring the relatively clean living and environmental conditions of the wealthy sectors. Anti-lead movement leader Carlos Pilo referred to the poor sectors as "time bombs in the making": "They’re filling lands with foundry waste [...] There are already people living on that, and even desperate people who scavenge in the waste, salvaging metals and smelting them there, in the open air, in the middle of an area of vineyards and small farms, in order to recover a few kilos of metal" (cited in C. Amorín 2003b). Montevideo’s riverbanks have become a toxic "no man's land," Pilo told me. Former workers of nowshuttered industries, he said, are forced by the economic crisis from their homes and build makeshift settlements where "no one takes responsibility for what happens." While the Uruguay Natural national marketing campaign calls for the beautification of Montevideo's eastern coast and central parks and plazas for tourist consumption, the rest of the city largely suffers from the fumes of industrial emissions and the wastes of clandestine dumps, a process amplified in wealthy Atlantic coastal resorts such as Punta del Este (D. Renfrew 2004a).

Urban environmental degradation, which includes lead contamination, other forms of toxic pollution, inadequate sanitation, or the proliferation of illegal garbage dumps, further stigmatizes the already out-of-place residents of the asentamientos by linking them symbolically to their environmental surroundings. This symbolic denigration is coupled with the serious negative health outcomes of living in proximity to pollution with little means of reducing exposure or mitigating its impacts. Exposure to potent neurotoxins such as lead furthers a cruel spiral in which behavioral problems, reduced intellectual achievement, and attention deficits impact school performance and further stigmatize poor children as unruly and destined for failure.

\section{The return of the chimney dreamers and the margin of contamination}

Musing on the likely rise of the FA to national power, Eduardo Gudynas of the CLAES environmental research center warned in a 2004 essay about the return of the "chimney dreamers" (los

\footnotetext{
${ }^{5}$ For example, a malnourished child who does not ingest adequate amounts of iron and calcium will absorb lead more quickly, and the heavy metal eventually replaces calcium in the bones. For this reason, the Public Health Ministry gives children with severe lead poisoning in Uruguay monthly deliveries of iron and calcium fortified foods.
} 
soñadores de chimeneas), by which he meant those who would return to a classic development model of favoring investment through smokestack industries at the expense of environmental concerns. The argument, which Gudynas traces to what he characterizes as the typical 1960s and 1970s position of the left, is that given the state of poverty and economic inequality the "luxury" of environmental protection cannot be afforded. Environmental regulation itself, according to this argument, is nothing but a tool of the imperialist North to hinder development in the South (E. Gudynas 2004).

While raising important concerns, Gudynas fails to recognize the extent to which Uruguayan political discourse, including that of the left, has greened in recent years. The Vázquez administration has fully embraced the Uruguay Natural campaign and the ideology of sustainable development. In his inauguration speech, Vázquez spoke at length about the value of rural ecology and his passion for fishing, suggesting the importance his administration would place on environmental protection. Despite the FA's longstanding anti-neoliberal ideology, however, the Vázquez administration has pursued its goal of a reinvigorated "productive country" (país productivo) through a blend of statist and orthodox neoliberal policies, as well as "public-private" partnerships. Both the previous Batlle and current Vázquez administrations have followed in general terms the tenets of ecological modernization, attempting to reconcile economic growth with an environmental protection directed by scientific management (D. Harvey 1996: 336).

Public prosecutor Enrique Viana, dubbed the "green prosecutor" by the Uruguayan press for his path-breaking role in environmental litigation, characterized the complex environmental legal framework put into place since the 1990s as a "trap."6 The MVOTMA (Housing, Territorial Regulation and Environment Ministry) was created in 1990, followed in the next decade by the passing of an Environmental Impact Law, the reform of Article 47 of the Constitution declaring the environment of general interest, and the Law of Protected Areas. Recent years have witnessed what Viana referred to as the "arrival of the monsters," or powerful multinational industries from Europe and North America such as chemical factories and large-scale pulp mills. Viana hypothesized that the "monsters" could not have invested in Uruguay without an existing environmental legal framework, which in effect served as a "landing strip" for the arrival of the multinationals.

Following the Forestry Law of 1987, for instance, commercial plantations of eucalyptus and pine grew exponentially, as foreign investors took advantage of ecological conditions that allow for rapid growth of commercial trees. Tree plantations in Uruguay grew from 145,000 hectares in 1990 to 660,000 hectares in 2004 (Achkar et. al. 2004: 151). In recent years, the plantations have served as primary resources for a series of multinational pulp mill mega-projects. The Batlle administration in 2003 first announced the construction of a new private port along the Uruguay River near the small western town of Fray Bentos to serve the planned multi-billion dollar investments of the Spanish Ence and Finnish Metsa-Botnia corporations. Multinational pulp firms from Sweden, Norway, the United States and Japan later announced intentions of constructing mega-projects along the eastern band of the Uruguay River as well as along the Río Negro in central Uruguay. These factories would complement Botnia, operational since 2007, and the still-under construction Ence. President Vázquez, once opposed to the projects, has since fully embraced them. The Vázquez and Batlle administrations together set in motion a strategic reorientation of the Uruguayan economy towards facilitating unprecedented large-scale investments of foreign capital to exploit Uruguay's abundant water and land resources. Uruguay has thereby charted a neoliberal strategy of foreign investment in key sectors through a process of accumulation by dispossession, or the "subsumption" of the nonhuman world by means of market logic (N. Castree 2008).

Uruguay has constructed a significant legal framework to regulate and manage the environment, but without the capacity or resources for effective oversight, leading to the "perfect scam," in Viana's words. The Uruguayan State does not have the capacity to manage environmental emergencies, as he noted became clear through the lead issue. Free trade and other multilateral investment agreements, meanwhile, set a host of advantages and guarantees for industries that invest in Uruguay. In the case of Botnia, Uruguay and Finland signed a bilateral investment pact that, among other measures, outlawed domestic political disturbances that could disrupt production at Botnia. In quintessential neoliberal fashion, it became the Uruguayan state's responsibility to discipline its subjects and ensure the political stability and "good business climate" for Botnia to maintain its operations.

\footnotetext{
${ }^{6}$ The following information is drawn from the author's interview with Enrique Viana, November 22, 2005.

${ }^{7}$ The pulp mill projects have drawn strong protests from Argentines in the Uruguay River border city of Gualeguaychú, across from the Botnia site, as well as from some environmentalists, small-scale agricultural producers, and other groups in Uruguay. The high profile and unprecedented bi-national conflict has provoked a nationalist and anti-environmentalist backlash in Uruguay. Argentine activists have blocked bridges connecting to Uruguay and have engaged in highly visible and creative protests, while each national government has argued its case before the World Court at The Hague. The Ence company moved its planned mill from its original site near Fray Bentos and the Botnia mill, to one further south near Conchillas, Department of Colonia. The company officially denies the move corresponded to political pressures from Argentina, but this is likely the case.
} 
Viana compared the 2000 Law of Environmental Protection with the still unregulated Law of Protected Areas and the drafted Law of Territorial Planning (Ley de Ordenamiento Territorial) in what he said was a designed division of the country into "productive" and ecologically-devastated areas on the one hand, with what he called "environmental museums" of protected areas to show what "Uruguay once was." According to this strategy, the east coast tourist goldmines would be left relatively untouched, but the center of the country would be transformed into a receptor of industrial waste from the large-scale industrial establishments in the central and western parts of the country, as well as the capital.

The suspicions expressed by Viana transcend the Uruguayan government and the multinationals. He charged that UN agencies such as the UNEP (PNUMA) ${ }^{8}$ are "in a sense playing the game for the European Community. In other words, to alleviate the contamination problem for the European Community, in some way they are opening doors for them to establish themselves here." Uruguayan officials, including MVOTMA Sub-Secretary Jaime Igorra, have received these investments with open arms, even justifying anticipated environmental degradation as falling within a reasonable "margin of contamination," given Uruguay's relatively unindustrialized territory:

Some authorities from here have said that Uruguay has to give itself a margin... that Uruguay has a margin for contamination. In a way there's a comparison being made with Europe. We can still cover that margin, instead of valorizing that margin, of trying to maintain it as it is...

Viana equated this practice to "importing contamination." In other words, through strategies of accumulation by dispossession, European countries export contaminating industries away from their long polluted environments, while benefiting from the cheaply available, and ultimately expendable, land, human, and water resources of Uruguay.

\section{The green veiling of capital}

As Uruguayan society greened in the past decade, many industries followed suit, marketing discourses of "eco-friendly" production practices and the minimizing of the ecological "footprints" of their actions. Large industries have for the first time dedicated resources to hiring public relations operatives and have formed environmental quality divisions in an attempt to offset or preempt scrutiny from environmentally conscious citizens and newly instituted state and local environmental regulations.

Botnia and Ence, for instance, have sponsored various community development projects, sports teams and cultural events in Fray Bentos and western Uruguay. Botnia has funded "ecological" children's television programming and signed a deal to transform local elementary schools into "ecological schools" that would teach children to care for new company-sponsored nature reserves of indigenous flora and fauna. The result of these unprecedented practices in Uruguay has been the symbolic and even biophysical draping of a broad veil of green over industrial practices. This green veiling transcends the actions of individual industries by presenting a compelling narrative, supported by high profile, strategic and well-funded visual evidence, that socially and ecologically responsible and sustainable development is indeed possible.

The Uruguayan state is fully complicit in the green veiling of capital, often by means of referencing the existence of environmental protocols and legislative frameworks. The Environmental Impact Assessment (EIA) protocol, for example, has been used by both the Batlle and Vázquez administrations to justify the construction of the pulp mills. Vázquez has repeatedly assured skeptics that Botnia and Ence passed the EIA process and the National Environmental Directorate (DINAMA) would conduct "rigorous" monitoring of the plants' effluents. Appealing to the existence of an EIA protocol or of a national environmental office can be used as a stand-in for actual scrutiny. They act as rubberstamps of approval on proposed projects, justified because they respond ultimately to "international" standards of science and regulation. What is meant specifically and what is addressed by these standards is seldom shared with the public, such as the bases of regulatory standards, how much pollution is "acceptable," or what constitutes a risk or hazard. International protocols become artifacts, reified as stand-alone objects that trump criticism, rather than the processual, information-sharing and openly democratic tools they portend to be. Trust is placed in the protocol itself, in the naming and conjuring of the regulation, and in the administrative rationalism of the technocrats and experts designated as the overseers and managers of industrial production.

The symbolic or discursive greening of the upper or large-scale circuits of capital coincides and coexists with open degradation at the lower and small-scale circuits. Work conditions and levels of unionization generally mirror this dual productive process. As large-scale factories green, smaller ones are implicated in contaminating and degrading the environment, communities, and bodies. Industrial greening

\footnotetext{
${ }^{8}$ United Nations Environment Program (UNEP), or Programa de las Naciones Unidas para el Medio Ambiente (PNUMA)
} 
strategies and grassroots environmentalist critique are both new to Uruguay, reflecting and setting the stage for a new language, new legitimating tools, and new forms of contestation oriented around nature and the environment. Taken together, they form a complementary relationship in which officials and industry representatives may point to the actions at the upper echelons of capital as evidence of official and corporate environmental responsibility and compliance, distracting from what is occurring elsewhere.

Citing the signing of various international treaties and agreements, or that a particular development project has been subjected to the EIA process, becomes a way of legitimizing existing local production processes without fundamentally altering the conditions of production. The bureaucratic employing of green discourse serves as a diversionary "anti-politics machine" (J. Ferguson 1994) or as a "displacing narrative": an aestheticized, non-political discourse that distracts from the actual productive processes underway while maintaining close ties to an orthodox development agenda (P. Brosius 1999: 286).

\section{Conclusion: From the margins of contamination}

This paper has analyzed nature and the environment in relation to broader Uruguayan histories of development, and state and societal transformations. Neoliberal globalization has resulted in profound transformations of the Uruguayan economy, state, society, and nature, largely ending the longstanding reign of the "hyper-integrated" batllista society. Nature in neoliberal times has drawn increased salience as an accumulation strategy, whether through the promotion of beach and eco-tourism or commercial forestry and multinational mega-factories.

While becoming streamlined and reducing its welfare functions as corresponds to a neoliberal agenda, the Uruguayan state has also expanded bureaucratically by creating a sophisticated regulatory apparatus in the strategic area of the environment. I have argued that this bureaucratic expansion and the setting up of a showcase ecology are eminently compatible with neoliberalism. They are indeed necessary to assure the favorable investment climate for Uruguay's deepened insertion into the global capitalist division of production. In other words, rather than being a hindrance to capital accumulation, the environmental regulatory apparatus becomes its "lubricant." State regulation is unlikely to "get in the way" of development, whether due to a lack of political will or to inadequate resources and technical capacity. Uruguay's environmental "paradox," meanwhile, is that parallel to its showcase ecology, neoliberal policy has resulted in serious processes of rural and urban environmental degradation. The streamlining of the state in areas of social provision, finally, increases vulnerability to affliction, making environmental diseases such as lead poisoning more likely and even predictable.

In Uruguay, grassroots and NGO pressures have played a major role in the ideological opposition to neoliberalism and capitalism's cost crisis. The rise of grassroots environmental mobilizations in Uruguay, developing largely in parallel with and external to both NGOs and the political left, reflects some of the liberating potentials of environmental action. But it also underscores the contested constructions of nature and the environment. Most grassroots environmental movements in Uruguay organize around issues related to the urban environment. Urban ecology, nevertheless, is often left out of the discourses, agendas, and evaluations of international environmental institutions and their Uruguayan counterparts. To discuss or analyze the state of the environment without paying attention to urban soils, waterways and air quality, particularly in an overwhelmingly urbanized country such as Uruguay, masks the real environmental problems faced every day by its citizens. In highlighting a largely contrived showcase ecology, furthermore, business leaders and government officials display the capitalist interests that lurk behind the rhetoric of environmental concern and sustainability, while reinforcing a popular assessment of environmentalism as an elitist preoccupation irrelevant to human needs.

As the Uruguayan case suggests, environmentalism can serve both emancipatory and repressive functions: as a vehicle for the claiming of rights and justice (D. Harvey 1996; D. Schlosberg 2003), and as means of social control and governance (A. Agrawal 2005; T. Luke 1995). Environmental governance may neutralize opposition, and in Uruguay it is enacted through the country's insertion into a global environmental regulatory regime. Government officials and business leaders promote discourses and practices of sustainable development that showcase ecological splendor for some, while veiling the entire regions and populations that are rendered as surplus to the needs of development. The lead issue has signified an unexpected rupture in the machinations of Uruguay's official environmental strategy, however, and has revealed a divide in competing organizational, institutional, and grassroots constructions of nature. Anti-lead activists have called for the protection of the environment, but always and necessarily in reference to, and dialogue with, human habitation and experience. They have petitioned or employed the same environmental regulatory frameworks, ideological tools, and political opportunities, but to further their own contestatory goals. Politically radicalized by the direct experience of living in the margins of contamination that Uruguayan officials are willing to sacrifice, grassroots environmental movements such as these may offer a roadmap for a more autonomous political opposition to the ostensibly "left" governments of Uruguay and the region, as well as to the processes of neoliberalization that are fundamentally reconfiguring society and nature. 


\section{References Cited}

Achkar, M., R. Cayssials, and A. Domínguez.

1999. Desafíos para Uruguay. Espacio agrario, espacio ambiental. Montevideo: Nordan Comunidad.

Agrawal, A.

2005. Environmentality. Technologies of government and the making of subjects. Durham and

Amorín, C. London: Duke University Press.

2003. Daniel Panario. La frivolidad ambiental del Uruguay. Brecha. Montevideo. December 26.

Anido, C., M. Achkar, G. Zorrilla, and M. de la Torre.

2000. Agua. Diagnóstico y propuestas hacia una gestión más sustentable. In Uruguay Sustentable. Una propuesta ciudadana, 401-449. Montevideo: REDES.

Apezteguía, P.

Babb, F.

2007. La nueva política habitacional. Brecha. Montevideo. January 12.

2001. After Revolution. Mapping gender and cultural politics in neoliberal Nicaragua. Austin: University of Texas Press.

Barringer, F.

2005. Nations ranked as protectors of the environment. The New York Times. New York. January 24.

Bernardi, R., and T. Paez.

1999. Contaminación hídrica por plomo en Montevideo. (Report). Unidad de Efluentes Industriales, Intendencia de Montevideo. Montevideo, Uruguay.

Bridge, G., and A. Jonas.

2002. Governing nature: the reregulation of resource access, production, and consumption. Environment and Planning A 34:759-766.

Brosius, P. J.

1999. Analyses and interventions: anthropological engagements with environmentalism. Current Anthropology 40:277-309.

Caffera, $M$.

2004. The implementation and enforcement of environmental regulations in a less developed market economy: evidence from Uruguay. Ph.D. Dissertation, University of Massachussetts.

Campomar, A., and B. M. Andersen. 1999. Uruguay. Open for growth. Coventry, England: Euromoney Publications.

Canak, W. L. Editor. 1989. Lost promises. Debt, austerity, and development in Latin America. Boulder, CO: Westview Press.

Castree, $\mathrm{N}$.

2008. Neoliberalising nature: the logics of deregulation and reregulation. Environment and Planning

Collier, G. A 40:131-152.

Corboz, J.

1999. Land and the Zapatista Rebellion. Oakland: Food First Books.

Coronil, F.

2005. Urban to peri-urban squatter settlement migration in Montevideo, Uruguay. Three60:21-24.

1997. The magical state: nature, money, and modernity in Venezuela. Chicago and London: University of Chicago Press.

Edelman, $\mathrm{M}$

1999. Peasants against globalization. rural social movements in Costa Rica. Stanford, CA: Stanford University Press.

Escobar, A.

1999. After nature: steps to an antiessentialist political ecology. Current Anthropology 40:1-30.

Escobar, A

1996. Constructing nature: elements for a poststructural political ecology. In Liberation ecologies: environment, development, social movements, eds. R. Peet and M. Watts. London and New York: Routledge.

Evia, G.

2002 Uruguay, segundo en América en calidad ambiental o el mito de maracaná

CLAES. http://www.claes.org.uy [accessed 14 January 2007]

Ferguson, J.

1994. The anti-politics machine: "development," depoliticization, and bureaucratic power in Lesotho. Minneapolis: University of Minnesota Press. 
Ferradás, C. A.

1996. El interjuego de lo global y local en la represa de Yacyretá. In América Latina en tiempos de globalización: procesos culturales y transformaciones sociopolíticas, eds. D. Mato, M. Montero, and E. Amodio, pp. 83-97. Caracas, Venezuela: Centro Regional para la Educación Superior en América Latina y el Caribe (CRESALC).

Ferradás, C.A.

1998. Power in the southern cone borderlands. an anthropology of development practice. Westport, CT and London: Bergin and Garvey.

Ferradás, C.A.

2004. Environment, security, and terrorism in the trinational frontier of the southern cone. Identities: global studies in culture and power 11:417-442.

Franklin, S., C. Lury, and J. Stacey.

Gledhill, J. 2000. Global nature, global culture. London: Sage.

1995. Neoliberalism, transnationalism and rural poverty. a case study of Michoacán, Mexico. Boulder, CO: Westview Press.

Goodman, A., and M. Watts. Eds. Gudynas, E. 1997. Globalising food: agrarian questions and global restructuring. London: Routledge.

2004. Regresaron los soñadores de chimeneas. La Insignia. http://www.lainsignia.org/2004/junio/econ_005.htm [accessed June 3, 3004]

Hartwick, E., and R. Peet. 2003. Neoliberalism and nature: the case of the WTO. Annals of the American Academy of Political Harvey, D. and Social Science 590:188-211.

Harvey, D. 1996. Justice, nature and the geography of difference. Oxford, UK: Blackwell.

Harvey, D. 2005. A brief history of neoliberalism. Oxford: Oxford University Press.

2006. Spaces of global capitalism: towards a theory of uneven geographical development. London: Verso.

Legnani, R.

2002. En Uruguay con plomo en tu cuerpo. Fundamentos para efectuar determinación sistemática de niveles de plomo en sangre de niños, embarazadas y trabajadores. Montevideo, Uruguay. Luke, T. Cámara de Diputados, República Oriental del Uruguay: Imprenta La Canasta s.r.l.

1995. On environmentality: geo-power and geo-knowledge in the discourses of contemporary environmentalism. Cultural Critique 31:57-81.

2006. The System of sustainable degradation. Capitalism, Nature, Socialism 17:99-112.

Muniz, P., E. Danulat, B. Yannicelli, J. García-Alonso, G. Medina, and M. C. Bícego.

2004. Assessment of contamination by heavy metals and petroleum hydrocarbons in sediments of Montevideo Harbour (Uruguay). Environment International 29:1019-1028.

MVOTMA.

2002. Informe de la República Oriental del Uruguay a la cumbre mundial sobre desarrollo sostenible. Johannesburg, 2002.

OSE.

2007. Press release regarding water quality in Montevideo and Canelones Departments. August 20, 2007.

Panario, D., M. Achkar, and J. P. Aicardi.

2000. Sector agropecuario. Diagnóstico y escenarios sustentables. In Uruguay Sustentable. Una propuesta ciudadana, 17-159. Montevideo: REDES.

Radcliffe, S. A.

2005. Neoliberalism as we know it, but not in the conditions of its own choosing: a commentary.

Renfrew, D. Environment and Planning A 37:323-329.

2004a. Punta del este as global city? Competing visions of Uruguayan nationhood in a geography of exclusion. City and Society 16:11-34.

Renfrew, D.

2004b. Frente Amplio wins elections in Uruguay. World Socialist Web Site. http://www.wsws.org/articles/2004/nov2004/urug-n04.shtml [accessed November 4, 2004]

Renfrew, D.

n.d. New hazards and old disease: lead contamination and the Uruguayan battery industry. Unpublished manuscript. 
Sachs, W.

1999. Sustainable development and the crisis of nature: on the political anatomy of an oxymoron. In Living with nature. environmental politics as cultural discourse, ed. F. Fischer and M. Hajer. Schlosberg, D. Oxford: Clarendon.

2003. The justice of environmental justice: reconciling equity, recognition, and participation in a political movement. In Moral and practical reasoning in environmental practice, eds. A. Light and A. De-Shalit. Cambridge, MA: MIT Press.

Shutz, A., L. Barregard, G. Sallsten, J. Wilske, N. Manay, L. Pereira, and Z. A. Cousillas. 1997. Blood lead in Uruguayan children and possible sources of exposure. Environmental Research 74:17-23.

Smith, N.

1996. The production of nature. In Future?Natural. Nature/Science/Culture, ed. G. Robertson. London and New York: Routledge.

SMU.

2001. Contaminación por plomo. Informe elaborada por la Comisión de Salud Ocupacional Sindicato Médico del Uruguay. Sindicato Médico del Uruguay.

Tong, S., Y. von Shirnding, and T. Prapamontol.

2000. Environmental lead exposure: a public health problem of global dimensions. Bulletin of the Trigo, A. World Health Organization 78:1068-1077.

1990. Caudillo, estado, nación. literatura, historia e ideología en el Uruguay. Gaithersburg, MD: Ediciones Hispamérica.

\begin{abstract}
The article situates a lead poisoning epidemic in Uruguay within recent processes of neoliberal and environmental reform. It argues industrial contamination and its socio-political responses have become prevalent through neoliberal-inspired transformations in production and consumption, the dismantling of state services, and increased social vulnerability to affliction. Contrary to orthodox theories of neoliberal restructuring, however, environmental concerns have provoked state bureaucratic expansion, rather than contraction, bringing about new forms of environmental governance and enabling environmental politics across social scales. Neoliberal reforms in Uruguay have resulted in geographically uneven spatial arrangements, with ecology taking on central importance in both macro-level development strategies as well as in grassroots responses to intensified or newly recognized socio-environmental hazards. This article analytically draws together neoliberalism and environmentalism, or "neoliberal nature" in Uruguay. It shows how neoliberal engagements with nature and the environment structure risk for masses of people, providing the political tools for both environmental governance and the contestation of environmentally destructive practices.
\end{abstract}

Keywords: lead poisoning, neoliberalism, environmentalism, sustainable development, Uruguay

\title{
Résumé
}

L'article relie l'empoisonnement au plomb en l'Uruguay avec les processus de réforme néo-libérale et de l'environnement. Elle fait valoir que la contamination industrielle et des réponses socio-politiques sont liées à les transformations de la production et de consommation, le démantèlement des services de l'Etat, et l'augmentation de la vulnérabilité sociale à l'empoisonnement. Contrairement aux théories orthodoxe de la restructuration néo-libérale, les préoccupations environnementales ont provoqué l'expansion bureaucratique d'État, plutôt que de la contraction. Cela a entraîné de nouvelles formes de gouvernance environnementale et la politique de l'environnement à travers les échelles sociales. Les réformes néolibérales en Uruguay ont abouti à des arrangements géographiquement inégale. L'écologie et les risques socio-environnementaux ont pris une importance centrale à la fois au niveau macro des stratégies de développement, ainsi que a la base (grassroots). Cet article rassemble le néolibéralisme et la protection de l'environnement, ou "la nature néolibérale" de l'Uruguay. Il montre comment néo-libéralisme crée de nouveaux risques. Cette politique prévoit des outils de gestion de l'environnement, mais aussi la contestation des pratiques destructrices de l'environnement.

Mots-clés: L'empoisonnement au plomb, néolibéralisme, écologie, développement durable, Uruguay 


\section{Resumen}

Este trabajo sitúa a una epidemia de contaminación por plomo en Uruguay en relación con recientes reformas neoliberales y ambientales. Propone que la contaminación industrial y sus respuestas socio-políticas han aumentado a través de las transformaciones neoliberales en la producción y el consumo, en el desmantelamiento de servicios del estado, y a través de un auge de vulnerabilidad a la aflicción social. Contrario a teorías ortodoxas de la reestructuración neoliberal, sin embargo, los problemas ambientales han provocado una expansión burocrática estatal, en vez de su retroceso, dando lugar tanto a nuevas formas de gobernabilidad ambiental como de nuevos movimientos ambientalistas. Las reformas neoliberales en Uruguay han resultado en arreglos espaciales geográficamente desiguales, mientras la ecología ha tomado suma importancia tanto en las estrategias de macro desarrollo económico, como en las respuestas de base a riesgos socio-ambientales intensificados o nuevamente descubiertos. Este trabajo reúne analíticamente al neoliberalismo con el ambientalismo, o la "naturaleza neoliberal" en Uruguay. Demuestra que las intervenciones neoliberales en la naturaleza y el ambiente estructura el riesgo para las masas, y ofrece a su vez herramientas políticas tanto para la gobernabilidad ambiental como para las respuestas contestatarias a prácticas ambientalmente destructivas.

Palabras clave: contaminación por plomo, neoliberalismo, ambientalismo, desarrollo sustentable, Uruguay 